\title{
Effect of Fresh Gas Flow Rate on Thiol/Disulphide Hemostasis and Ischemia-modified Albumin in Laparoscopic Cholecystectomy
}

\author{
Sermin Eminoglu ${ }^{1}$, Seyda Efsun Ozgunay ${ }^{1}$, Umran Karaca ${ }^{1}$, Asiye Demirel ${ }^{1}$, Mehmet Gamli ${ }^{1}$, Yasemin Ustundag $^{2}$, \\ Derya Karasu ${ }^{1}$, Hasan Eroglu ${ }^{3}$ and Ozcan Erel $^{4}$ \\ ${ }^{1}$ Department of Anaesthesiology and Reanimation, Health Science University, Bursa Yuksek Ihtisas Training and Education Hospital, \\ Bursa, Turkey \\ ${ }^{2}$ Department of Biochemistry, Health Science University, Bursa Yuksek Ihtisas Training and Education Hospital, Bursa, Turkey \\ ${ }^{3}$ Department of General Surgery, Yalova State Hospital, Yalova, Turkey \\ ${ }^{4}$ Department of Biochemistry, Health Science University Ankara Yildirim Beyazit Training and Education Hospital, Ankara, Turkey
}

\begin{abstract}
Objective: To investigate the effects of low-flow and high-flow anesthesia techniques, administered with sevoflurane during laparoscopic cholecystectomy, on thiol/disulphide homeostasis and serum ischemia-modified albumin (IMA) levels.

Study Design: Double-blind, randomised study.

Place and Duration of Study: Department of Anesthesiology and Reanimation, Health Science University, Bursa Yuksek Ihtisas Training and Education hospital, Bursa, Turkey from January to October 2020.

Methodology: Patients over the age of 18 years, scheduled for elective laparoscopic cholecystectomy, were included in the study. The patients were divided into two groups: Group 1 (low-flow, 1 L/min) and Group 2 (high-flow, 2 L/min). The blood samples for thiol/disulphide homeostasis and serum IMA levels were collected as follows: 5 minutes before induction of anesthesia (T0), 5 minutes after induction of anesthesia (T1) and postoperative $24^{\text {th }}$ hour (T2).

Results: The final analysis included 104 patients. The two groups did not differ significantly in terms of any of the demographic characteristics $(p>0.05)$. There were also no inter-group differences in terms of thiol/disulphide homeostasis parameters or serum IMA levels at T0, T1, or T2. However, in both groups, there were statistically significant changes in serum disulphide and IMA levels from T0 to T1 and T0 to T2 ( $p=0.000$, and $p=0.005$, respectively).

Conclusion: There was no difference between low-flow and high-flow anesthesia during laparoscopic cholecystectomy in terms of hemodynamics or thiol/disulphide homeostasis.

Key Words: Low-flow anesthesia, High-flow anesthesia, Thiol/disulphide homeostasis, Ischemia-modified albumin (IMA), Laparoscopic cholecystectomy.

How to cite this article: Eminoglu S, Ozgunay SE, Karaca U, Demirel A, Gamli M, Ustundag Y, Karasu D, Eroglu H, Erel O. Effect of Fresh Gas Flow Rate on Thiol/Disulphide Hemostasis and Ischemia-modified Albumin in Laparoscopic Cholecystectomy. J Coll Physicians Surg Pak 2022; 32(02):141-146.
\end{abstract}

\section{INTRODUCTION}

The imbalance between reactive oxygen species and antioxidant defense mechanisms is referred to as oxidative stress. Anesthesia method, surgical method, used medicines, infection and operation time, can change the stress response and affect postoperative morbidity and mortality. ${ }^{1}$

Correspondence to: Dr. Sermin Eminoglu, Department of Anaesthesiology and Reanimation, Health Science University, Bursa Yuksek Ihtisas Training and Education

Hospital, Bursa, Turkey

E-mail: sereminoglu1616@gmail.com

Received: August 27, 2021; Revised: November 27, 2021;

Accepted: December 22, 2021

DOI: https://doi.org/10.29271/jcpsp.2022.02.141
Anesthesia can be performed with both low and high fresh gas flow. High quality standards for anesthesia machines have ensured the safe implementation of low-flow anesthesia. Lowflow anesthesia refers to inhalational anesthesia, using a semi-closed system with a rebreathing rate of at least $50 \%$. All of the flow rates less than $1 \mathrm{~L} / \mathrm{min}$ can also be grouped and defined as low-flow anesthesia. Low-flow anesthesia has several advantages. These include reduction in the use of inhalational anesthetics, improved body temperature and humidity homeostasis, decreased environmental pollution and significance cost saving. ${ }^{2-5}$

Volatile anesthetic agents used for general anesthesia, such as desflurane and sevoflurane, can cause oxidative stress due to increased lipid peroxidation or proinflammatory cytokines in macrophages. ${ }^{6}$ Moreover, the increased intra-abdominal pres- 
sure resulting from the pneumoperitoneum necessary for laparoscopic cholecystectomy can cause mesenteric hypoxia, ischemia-reperfusion injury, and oxidative stress in hepatic splanchnic veins. ${ }^{7}$

Thiol is an antioxidant tampon compound that contains sulfur and a hydrogen atom. It is oxidised by surrounding oxidant molecules and converted into disulphuric materials and then thiol groups. Apoptosis plays critical roles in detoxification, antioxidant protection, and cellular enzyme regulation. ${ }^{8-10}$ Serum thiol levels indirectly reflect antioxidant protection. IMA can also be used as a perioperative ischemia marker. ${ }^{11}$ IMA formation results from hypoxia, acidosis, and superoxide radical damage causing changes in the $\mathrm{N}$-terminal of albumin, which reduces bonding between metals and albumin. IMA levels rise rapidly in the context of ischemia. ${ }^{12,13}$

Anesthetic applications with these two forms of flow were thought to have different effects on oxidative stress parameters.

This study investigated and compared the effects of low-flow vs. high-flow anesthesia with sevoflurane on thiol/disulphide homeostasis and IMA during la paroscopic cholecystectomy.

\section{METHODOLOGY}

This study was conducted at Health Science University, Bursa Yuksek Ihtisas Training and Education Hospital, Bursa, Turkey in accordance with the Declaration of Helsinki after local Ethics Committee approval (2011-KAEK-25 2020/01-21; and Clinical trials No. NCT04926480). All participants provided informed consent before taking part in the study. For this prospective, double-blind, randomised study, eligible patients were over 18 years of age; and classified as per American Society of Anesthesiologists (ASA) physical status Class I and Class II. The authors excluded patients with ASA Class III-IV, systemic infection, cerebrovascular disease, diabetes mellitus, renal disease, morbid obesity ( $\mathrm{BMI} \geq 35 \mathrm{Kg} / \mathrm{m}^{2}$ ), smokers and those taking medications such as non-steroid anti-inflammatory and steroid that could affect reduction-oxidation homeostasis. Using the sealed-envelope method, the authors divided patients into 2 groups: Group 1 (low-flow, 1 L/min, n=58) and Group 2 (high-flow, 2 L/min, $n=58$ ).

No patients were given premedications. For anesthesia induction and endotracheal intubation, the authors used $2-3 \mathrm{mg} / \mathrm{Kg}$ of intravenous (IV) propofol (Pofol ${ }^{\circledR}$, Ilsan-Iltas, Kocaeli, Turkey), $0.6 \mathrm{mg} / \mathrm{Kg}$ of IV rocuronium bromide (Curon ${ }^{\circledR}$, Mustafa Nevzat, Istanbul, Turkey), and 1-2 $\mu \mathrm{g} / \mathrm{Kg}$ of IV fentanyl (Talinat ${ }^{\circledR}$, Vem, İstanbul, Turkey). For general anesthesia maintenance, the initial 10 minutes were $4 \mathrm{~L} / \mathrm{min} 50 \%$ of oxygen and air mixture in a fresh gas, and inhaled 3\%-4\% sevoflurane (Sevorane ${ }^{\circledR}$, Abbvie, Istanbul, Turkey). After that, the flow rates were reduced to $1 \mathrm{~L} / \mathrm{min}$ and $2 \mathrm{~L} / \mathrm{min}$ for Group 1 and Group 2, respectively, and mixed with $2-3 \%$ sevoflurane. Respiratory rate and tidal volume were maintained, according to patient weight. End-tidal carbon dioxide level (etCO ${ }_{2}$ ) were maintained at 30-35 $\mathrm{mmHg}$ using the volume control method of the anesthesia device (DrägerPerseus ${ }^{\circledast}$ A500, Lübeck, Germany). During anesthesia, $0.5 \mu \mathrm{g} / \mathrm{Kg}$ of IV fentanyl and $0.2 \mu \mathrm{g} / \mathrm{Kg}$ of IV rocuronium bromide were administered. After post-deflation and removal of the trocar, the flow rate for both groups was increased to 4 $\mathrm{L} / \mathrm{min}$. After the initiations of spontaneous ventilation, $100 \%$ oxygen was supplied. Neuromuscular blockade was reversed with $0.5 \mathrm{mg}$ atropine IV (Atropin sülfat ${ }^{\circledR}$, Osel, İstanbul, Turkey) and $0.2 \mathrm{mg} / \mathrm{Kg}$ neostigmine IV (Neostigmine ${ }^{\circledR}$, Adeka, İstanbul, Turkey). When adequate spontaneous breathing was achieved, patients were extubated and transferred to the recovery room.

Perioperatively, the authors recorded heart rate $(H R)$, mean arterial pressure (MAP), peripheral oxygen saturation $\left(\mathrm{SpO}_{2}\right)$, and etCO $\mathrm{O}_{2}$ at the following times: immediate preoperative; then $5,10,15,30,45,60,90$, and 120 minutes after intubation; the after extubation. Total operation and anesthesia times were also recorded.

To determine thiol/disulphide homeostasis status and IMA levels, the authors drew 3-5 mL venous blood samples from each patient, each collected at a different time point: T0 (5 minutes before anesthesia induction), T1 (5 minutes after postdeflation), and T2 (postoperative $24^{\text {th }}$ hour).

The blood samples were collected into Vacusera clot activator tubes (Disera, Izmir, Turkey) and quickly centrifuged at 1500 rpm for 10 minutes to separate serum fractions that have been stored at $-80^{\circ} \mathrm{C}$, until the tests were carried out and sent to the lab to measure the following: IMA, native thiol, total thiol, disulphide, disulphide/native thiol ratio, disulphide/total thiol ratio, and native thiol/total thiol ratio.

Serum thiol and disulphide measurements were made via the automatic spectrophotometric method as described by Erel and Neşelioğlu. ${ }^{8}$ Thiol/disulphide homeostasis parameters were investigated during the same sessions with the serum samples. IMA was measured via the spectrophotometric method as described by Bar-Or et al. ${ }^{9}$ and the results are expressed as IMA absorption units.

To determine the required sample size, the authors conducted a pilot study with five patients in each group. After the pilot study, IMA measurements for both the high-flow and low-flow groups were conducted (standard deviation $=0.10$ ). Sample size calculation was performed with G*Power 3.1.9.7 software and with those measurements, an effect size of $0.57,80 \%$ power, and a $5 \%$ significance level, the authors decided on a sample size of 50 patients for each group. Statistical analyses were performed with IBM SPSS verion 23.0 (IBM Corp. Released 2015. IBM SPSS Statistics for Windows, Version 23.0. Armonk, NY: IBM Corp.). Continuous variables were expressed as mean \pm standard deviation or median (IQR: Interquartile range $25^{\text {th }}-75^{\text {th }}$ percentiles), and nominal variables were expressed as frequencies and percentages. The data were examined by the Shapiro-Wilk test, whether or not it presents normal distribution. Pearson Chisquare analyses were used to detect inter-group differences in terms of categorical variables. For responses at different time points, percent changes (percent change $\Delta=$ (last measure- 
ment - first measurement) / first measurement) were calculated, according to the baseline measurement. These percent changes were compared using the Mann-Whitney U-test and the Student's t-test for two groups. For within group comparison, paired data were analysed using paired samples ttest and the Wilcoxon signed rank test. A p-value less than 0.05 was considered statistically significant.

\section{RESULTS}

One hundred and thirty-seven patients, who underwent elective laparoscopic cholecystectomy, were included in the study. Among those, the authors excluded two patients with chronic renal failure, seven patients with diabetes mellitus, and twelve patients, who were classified as ASA Class III-IV. Furthermore, four patients underwent open cholecystectomy; and sample collection or coagulation was inadequate for eight patients. Finally, 104 patients were included in the analysis (Group 1, $n=54,51.92 \%$, Group 2, n=50,48.07\%, Figure 1). There was no significant difference between the groups in terms of demographic characteristics (TablesI, II).

Table I: Patients' demographic features.

\begin{tabular}{|c|c|c|c|}
\hline Variable & Group 1 & Group 2 & $\mathbf{P}$ \\
\hline Age, years (mean $\pm S D$ ) & $51.11 \pm 14.07$ & $52.30 \pm 13.83$ & $.665^{\mathrm{a}}$ \\
\hline $\begin{array}{l}\text { Gender, } \mathrm{n}(\%) \\
\text { Female } \\
\text { Male }\end{array}$ & $\begin{array}{l}39(72.2 \%) \\
15(27.8 \%)\end{array}$ & $\begin{array}{l}36(72.0 \%) \\
14(28.0 \%)\end{array}$ & $.980^{\mathrm{b}}$ \\
\hline $\begin{array}{l}\text { ASA n (\%) } \\
\text { I } \\
\text { II }\end{array}$ & $\begin{array}{l}26(48.1 \%) \\
28(51.9 \%)\end{array}$ & $\begin{array}{l}29(58.0 \%) \\
21(42.0 \%)\end{array}$ & $.315^{\mathrm{b}}$ \\
\hline BMI, (median(IQR)) & $\begin{array}{c}28.75 \\
(26.54-31.25) \\
\end{array}$ & $\begin{array}{c}30.86 \\
(26.10-33.73) \\
\end{array}$ & $.112^{c}$ \\
\hline $\begin{array}{l}\text { Comorbidity } \mathrm{n}(\%) \\
\text { Yes } \\
\text { No }\end{array}$ & $\begin{array}{l}29(53.7 \%) \\
25(46.3 \%)\end{array}$ & $\begin{array}{l}23(46.0 \%) \\
27(54.0 \%)\end{array}$ & $.432^{\mathrm{b}}$ \\
\hline Operation duration min (median(IQR)) & $45.00(35.00-60.00)$ & $50.00(35.00-60.00)$ & $.596^{c}$ \\
\hline Total anesthesia time, min (median(IQR)) & $62.50(50.00-75.00)$ & $62.50(50.00-80.00)$ & $.904^{c}$ \\
\hline $\begin{array}{l}\text { Descriptive statistics are shown as mean } \pm \text { standard dev } \\
\text { Anesthesiologists, BMI: Body mass index. " }{ }^{2} \text { Student's t-te } \\
\text { test wasused. }\end{array}$ & $\begin{array}{l}\text {, median (IQR) and n(\%). } \\
\text { sused, } \\
\text { s. Pearson Chi-Square }\end{array}$ & $\begin{array}{l}\text { ASA: American Society of } \\
\text { test wasused, 'Mann Whit }\end{array}$ & they $U$ \\
\hline
\end{tabular}

Table Il: Comorbidity distribution by groups.

\begin{tabular}{|l|c|c|c|}
\hline $\begin{array}{l}\text { Comorbid disease, } \\
\mathbf{n}(\%)\end{array}$ & Group I & Group II & $\mathbf{P}=\mathbf{8 0 5}$ \\
\hline HT & $19(35.2 \%)$ & $15(30.0 \%)$ & \\
\hline CAD-CHF & $5(9.3 \%)$ & $5(10 \%)$ & \\
\hline HT-CHF & $2(3.7 \%)$ & $1(2.0 \%)$ & \\
\hline COPD-Asthma & $2(3.7 \%)$ & $1(2.0 \%)$ & \\
\hline HT-CAD-COPD-Asthma & $3(5.6 \%)$ & $1(2.0 \%)$ & \\
\hline $\begin{array}{l}\text { Descriptive statistics are shown as n(\%), Pearson Chi-Square test was used. HT: } \\
\text { Hypertension, CAD-CHF: Coronary artery disease-Congestive heart failure, COPD: } \\
\text { Chronic obstructive pulmonary disease. }\end{array}$ \\
\hline
\end{tabular}

There were also no significant inter-group differences in terms of mean values of native thiol levels, total thiol levels, disulphide levels, disulphide/total thiol ratio, and IMA levels at T0, T1, or T2 (Table III). However, in both groups, there were statistically significant changes in serum disulphide and IMA levels from T0 to T1 and T0 to T2 ( $p<0.001$, and $p=0.005$, respectively, Table III).

In Group 1, the mean serum total thiol level, disulphide/native thiol ratio, and disulphide/total thiol ratio at T0 were significantly higher than those at T1 $(p=0.009, p=0.001$, and $p$ $<0.001$, respectively). The mean serum disulphide/native thiol ratio and the mean disulphide/total thiol ratio for Group 1 at T0 were also significantly higher than the values at T2 ( $p<0.001$, Table III).

In Group 2, the mean serum native thiol level, total thiol level, disulphide/native thiol ratio level and mean disulphide/total thiol ratio level at T0 were significantly higher than the mean levels at $\mathrm{T} 1(\mathrm{p}=0.021, \mathrm{p}=0.018, \mathrm{p}=0.017$ and $\mathrm{p}=0.012$, respectively). The mean disulphide/native thiol ratio and mean disulphide/total thiol ratio at T0 for Group 2 were found significantly higher than those at T2 $(p<0.001$ and $p=0.009$, respectively, Table III).

Perioperative mean HR and MAP values did not change significantly over time in either group; neither did intraoperative $\mathrm{SpO}_{2}$ or etCO $\mathrm{O}_{2}$ (Figures 2 and 3).

\section{DISCUSSION}

In this comparison of low-flow anesthesia with high-flow anesthesia with respect to their effects on thiol/disulphide homeostasis and IMA levels during laparoscopic cholecystectomy, there were no significant inter-group differences in the native thiol level, total thiol level, disulphide level, disulphide/total thiol ratio, native thiol/total thiol ratio or IMA level at T0, T1, or T2. However, there were significant intra-group changes in mean serum disulphide and IMA levels from T0 to T1 and T0 to T2.

There are several published articles reporting on oxidative stress markers in laparoscopic surgery. ${ }^{1,14,15}$ However, there was no literature comparing the effects of low-flow vs. high-flow sevoflurane anesthesia on the oxidative system in laparoscopic cholecystectomy, which enhances the value of this study.

Chemical compounds containing thiol, i.e., sulphydryl groups are important for protection against oxidative stress. ${ }^{16}$ Thiols and disulphides with oxidised forms are subject to a balance known as the dynamic thiol/disulphide homeostasis. The increase in favour of the disulphide form in the disulphide/native thiol and the disulphide/total thiol ratios can be accepted as indicative of oxidative stress. There are many investigations on the effects of peroperative use of anesthetic methods and agents on this balance. ${ }^{14,17-20}$

Generally, the inhalation anesthetic agent desflurane has been used in few studies in the literature on fresh gas flow rate. Batçık et al. using desflurane and propofol in tympanoplasty cases, investigated the effects of minimal-flow and high-flow hypotensive anesthesia on oxidative stress. ${ }^{21}$ They reported that in both the groups with minimal-flow and the high-flow applications, the native and the total thiol values were reduced, the intraoperative fall in the disulphide values were low showing the oxidative stress in both flow techniques, but that the groups did not differ significantly in terms of the thiol/disulphide homoestasis. 
Table III: Thiol/disulphide homeostasis and Ischemia-modified albumin levels.

\begin{tabular}{|c|c|c|c|c|c|c|c|}
\hline Parameters & & TO & T1 & T2 & $\mathbf{T} 1 \Delta$ & T2A & $\mathbf{p}$ \\
\hline \multirow{3}{*}{$\begin{array}{l}\text { Nativethiol } \\
(\mu \mathrm{mol} / \mathrm{L})\end{array}$} & Group $1(n=54)$ & $\begin{array}{c}486.5 \\
(430 \quad 544)\end{array}$ & $\begin{array}{c}473 \\
(405517)\end{array}$ & $\begin{array}{c}500 \\
(447 \quad 534)\end{array}$ & $\begin{array}{c}-0.05 \\
(-0.13 \quad 0.06)\end{array}$ & $\begin{array}{c}0 \\
(-0.09 \quad 0.08)\end{array}$ & $\begin{array}{ll}\text { To-T1 } & .044 \\
\text { To-T2 } & .884\end{array}$ \\
\hline & Group $2(n=50)$ & $\begin{array}{c}520.5 \\
(462577)\end{array}$ & $\begin{array}{c}479.5 \\
(424530)\end{array}$ & $\begin{array}{c}503 \\
(457531)\end{array}$ & $\begin{array}{c}-0.09 \\
(-0.21 \quad 0.12)\end{array}$ & $\begin{array}{c}-0.03 \\
(-0.17 \quad 0.15)\end{array}$ & $\begin{array}{ll}\text { To-T1 } & .021 \\
\text { To-T2 } & .169 \\
\end{array}$ \\
\hline & $p$ & \multicolumn{3}{|c|}{.162} & .380 & .332 & \\
\hline \multirow{3}{*}{$\begin{array}{l}\text { Total thiol } \\
\text { ( } \mu \mathrm{mol} / \mathrm{L})\end{array}$} & Group $1(n=54)$ & $\begin{array}{c}542 \\
(479597) \\
\end{array}$ & $\begin{array}{c}519 \\
(445 \quad 568)\end{array}$ & $\begin{array}{c}535 \\
(486 \quad 571) \\
\end{array}$ & $\begin{array}{c}-0.07 \\
(-0.14 \quad 0.05)\end{array}$ & 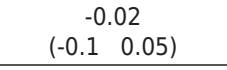 & $\begin{array}{ll}\text { To-T1 } & .009 \\
\text { To-T2 } & .201 \\
\end{array}$ \\
\hline & Group $2(n=50)$ & $\begin{array}{c}562.5 \\
(503622)\end{array}$ & $\begin{array}{c}524.5 \\
(472576)\end{array}$ & $\begin{array}{c}546 \\
(499577)\end{array}$ & $\begin{array}{c}-0.07 \\
(-0.19 \quad 0.07)\end{array}$ & $\begin{array}{c}-0.03 \\
(-0.15 \quad 0.09)\end{array}$ & $\begin{array}{ll}\text { To-T1 } & .018 \\
\text { To-T2 } & .152 \\
\end{array}$ \\
\hline & $\mathrm{p}$ & \multicolumn{3}{|c|}{.409} & .750 & .760 & \\
\hline \multirow{3}{*}{$\begin{array}{l}\text { Disulphide } \\
\text { ( } \mu \mathrm{mol} / \mathrm{L})\end{array}$} & Group $1(n=54)$ & $\begin{array}{c}25 \\
(24 \quad 26.5)\end{array}$ & $22(2024)$ & $\begin{array}{c}21.5 \\
(20.5 \quad 23.5) \\
\end{array}$ & $\begin{array}{c}-0.11 \\
(-0.2 \quad-0.04)\end{array}$ & $\begin{array}{c}-0.14 \\
(-0.2 \quad-0.06)\end{array}$ & $\begin{array}{ll}\text { To-T1 } & .000 \\
\text { To-T2 } & .000 \\
\end{array}$ \\
\hline & Group $2(n=50)$ & $\begin{array}{c}25 \\
(23.5 \quad 25.5)\end{array}$ & $\begin{array}{c}21 \\
(20.523)\end{array}$ & $21.5(20 \quad 23)$ & $-0.12(-0.21-0.06)$ & $-0.14(-0.19-0.08)$ & $\begin{array}{ll}\text { To-T1 } & .000 \\
\text { To-T2 } & .000 \\
\end{array}$ \\
\hline & $\mathrm{p}$ & \multicolumn{3}{|c|}{.344} & .571 & .961 & \\
\hline \multirow{3}{*}{$\begin{array}{l}\text { Disulphide/ } \\
\text { Nativethiol } \\
\text { ratio'100 }\end{array}$} & Group $1(n=54)$ & $\begin{array}{c}5.19 \\
(4.77 \quad 5.56)\end{array}$ & $\begin{array}{c}4.7 \\
(4.15 \quad 5.53)\end{array}$ & $\begin{array}{c}4.58 \\
(4.1 \quad 4.92)\end{array}$ & $\begin{array}{c}-0.09 \\
(-0.18 \quad 0.02)\end{array}$ & 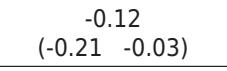 & $\begin{array}{ll}\text { To-T1 } & .001 \\
\text { To-T2 } & .000 \\
\end{array}$ \\
\hline & Group $2(n=50)$ & $\begin{array}{c}5.09 \\
(4.45 \quad 5.6)\end{array}$ & $\begin{array}{c}4.63 \\
(4.18 \quad 5.05) \\
\end{array}$ & $4.53(4.22 \quad 4.88)$ & $\begin{array}{c}-0.08 \\
(-0.22 \quad 0.06)\end{array}$ & $\begin{array}{c}-0.11 \\
(-0.22 \quad 0.03)\end{array}$ & $\begin{array}{ll}\text { To-T1 } & .017 \\
\text { To-T2 } & .000 \\
\end{array}$ \\
\hline & $\mathrm{p}$ & \multicolumn{3}{|c|}{.448} & .938 & .815 & \\
\hline \multirow{3}{*}{$\begin{array}{l}\text { Disulphide/ } \\
\text { Total thiol } \\
\text { ratio' } 100\end{array}$} & Group $1(n=54)$ & $\begin{array}{c}4.88 \\
(4.38 \quad 5.39)\end{array}$ & $\begin{array}{c}4.29 \\
(3.83 \quad 4.98)\end{array}$ & $\begin{array}{c}4.16 \\
(3.79 \quad 4.48)\end{array}$ & $\begin{array}{c}-0.09 \\
(-0.22 \quad 0.02)\end{array}$ & $\begin{array}{c}-0.11 \\
(-0.23 \quad-0.05)\end{array}$ & $\begin{array}{ll}\text { To-T1 } & .000 \\
\text { To-T2 } & .000 \\
\end{array}$ \\
\hline & Group $2(n=50)$ & $\begin{array}{c}4.53 \\
3.98 \quad 5.56) \\
\end{array}$ & $\begin{array}{c}4.24 \\
(3.85 \quad 4.59)\end{array}$ & $\begin{array}{c}4.28 \\
(3.78 \quad 4.58)\end{array}$ & $-0.09\left(\begin{array}{ll}-0.22 & 0.1\end{array}\right)$ & $-0.1\left(\begin{array}{ll}-0.2 & 0.06\end{array}\right)$ & $\begin{array}{ll}\text { To-T1 } & .012 \\
\text { To-T2 } & .009 \\
\end{array}$ \\
\hline & $p$ & \multicolumn{3}{|c|}{.077} & .515 & .191 & \\
\hline \multirow{3}{*}{$\begin{array}{l}\text { Nativethiol/ } \\
\text { Total thiol } \\
\text { ratio'100 }\end{array}$} & Group $1(n=54)$ & $\begin{array}{c}91.4 \\
(90.49 \quad 92.29)\end{array}$ & $\begin{array}{c}91.42 \\
(90.0592 .34)\end{array}$ & $\begin{array}{c}91.62(91.04 \\
92.42)\end{array}$ & $0\left(\begin{array}{ll}-0.02 & 0.01\end{array}\right)$ & $0\left(\begin{array}{ll}-0.01 & 0.02\end{array}\right)$ & $\begin{array}{cc}\text { To-T1 } & .547 \\
\text { To-T2 } & .423 \\
\end{array}$ \\
\hline & Group $2(n=50)$ & $\begin{array}{c}91.96 \\
(91.06 \quad 92.5)\end{array}$ & $\begin{array}{c}91.54 \\
(90.8292 .29) \\
\end{array}$ & $\begin{array}{c}92.05 \\
(91.1292 .46)\end{array}$ & $\begin{array}{c}-0.01 \\
(-0.01 \quad 0.02)\end{array}$ & $0\left(\begin{array}{ll}-0.01 & 0.01\end{array}\right)$ & $\begin{array}{cc}\text { To-T1 } & .409 \\
\text { To-T2 } & .622\end{array}$ \\
\hline & $\mathrm{p}$ & \multicolumn{3}{|c|}{.139} & .902 & .691 & \\
\hline \multirow{3}{*}{ IMA (ACU) } & Group $1(n=54)$ & $.875 \pm .08$ & $.805 \pm .06$ & $.809 \pm .05$ & $-.08 \pm .06$ & $-.07 \pm .09$ & $\begin{array}{ll}\text { To-T1 } & .000 \\
\text { To-T2 } & .000 \\
\end{array}$ \\
\hline & Group $2(n=50)$ & $.841 \pm .12$ & $.786 \pm .09$ & $.801 \pm .09$ & $-.06 \pm .12$ & $-.04 \pm .11$ & $\begin{array}{ll}\text { To-T1 } & .000 \\
\text { To-T2 } & .005\end{array}$ \\
\hline & $\mathrm{p}$ & \multicolumn{3}{|c|}{.141} & .680 & .187 & \\
\hline
\end{tabular}

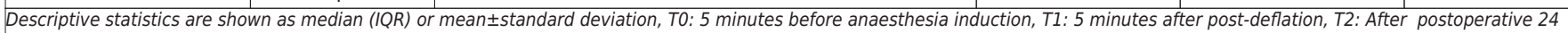

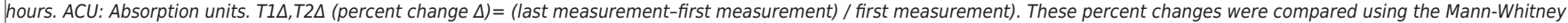
U-test and Student's t-test for two groups. For within group comparison, paired data were analysed using paired samples t-test and Wilcoxon Signed Rank test. $p<0.05$.

Tanriverdi et al. investigating the effects of minimal-flow and normal-flow desflurane anesthesia on the inflammatory parameters in laparoscopic cholecystectomy cases, showed that the postoperative inflammatory response with minimal-flow desflurane anesthesia was lower than that with the normal-flow desflurane anesthesia. ${ }^{2}$ Yüce et al. using desflurane and propofol, compared the costs and the effects of minimal-flow and low-flow anesthesia on oxidative stress in thyroid and/or parathyroid surgery. ${ }^{22}$ They emphasised the indication for greater care due to partly lowered antioxidant parameters despite the cost advantage of the minimal-flow anesthesia. In this study, the authors did not find any difference in antioxidant levels after desufflation and at $24^{\text {th }}$ hour in both low-flow and high-flow groups. However, the intragroup comparisons in both groups of the T0-T1 and T0-T2 serum disulphide and IMA levels showed the levels to be significantly high at T0. In contrast to all of these studies, the authors used sevoflurane as an inhalation anesthetic in this study. Protection against ischaemia-reperfusion damage by sevoflurane in vital organs such as the heart, lung and the kidney has been determined. ${ }^{14,18,19}$ The low disulphide and IMA levels as compared to baseline levels in both groups may be accepted as indicators of functioning antioxidant mechanisms. This may involve the protective effect of sevoflurane.

There are various studies on the effects of low-flow on haemodynamics. ${ }^{23-25}$ Dogan et al. did not oberserve any differences in haemodynamics, when investigating the intraoperative muscle relaxant consumption during minimal, low and medium-flow anesthesia. ${ }^{23}$ Kepekçi et al. comparing the minimal-flow (0.5 L/min), low-flow (1 L/min), and high-flow (2 $\mathrm{L} / \mathrm{min}$ ) anesthesia using sevoflurane, did not find significant intra-group differences in the mean values of the $H R$ and MAP measurements. ${ }^{24}$ Isık et al. demonstrated that desflurane and sevoflurane did not adversely affect the haemodynamic parameters in low-flow anesthesia. ${ }^{25}$ The present findings on haemodynamic parameters are in agreement with the literature. Statistically significant deifferences were not observed when groups were evaluated for etCO $\mathrm{C}_{2}$ ve $\mathrm{SpO}_{2}$. 


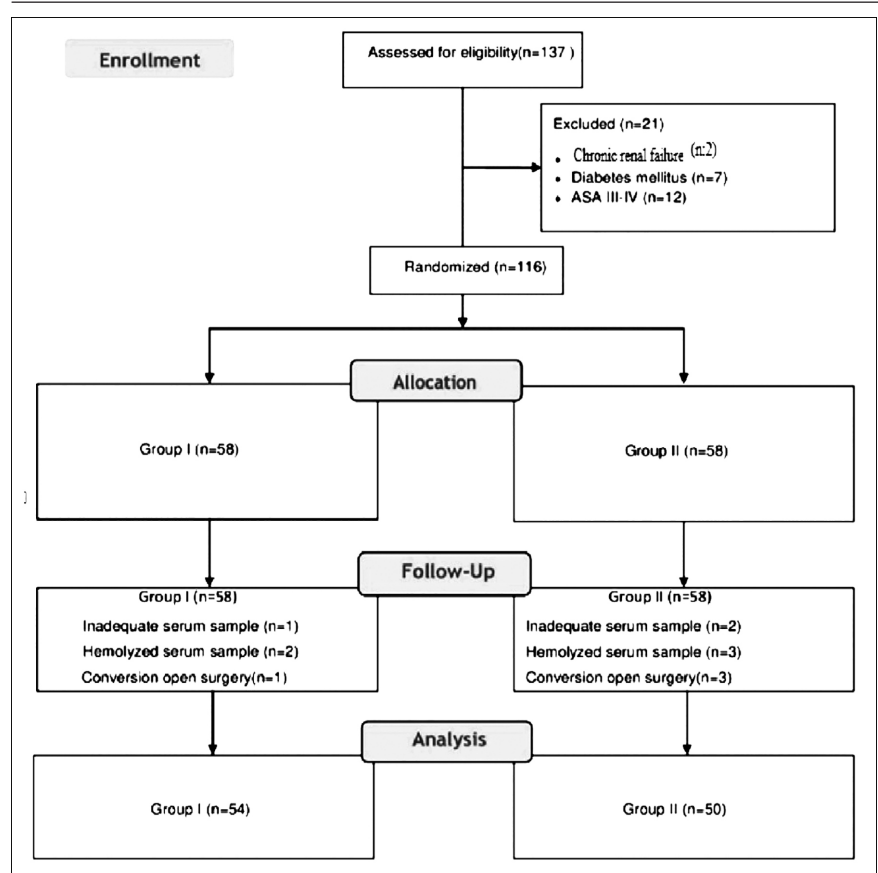

Figure 1: Flow chart of the study.

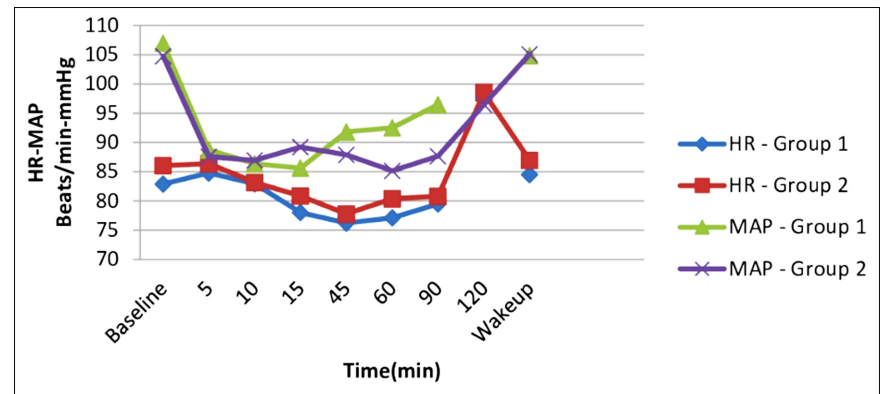

Figure 2: Change of HR and MAP according to time by groups.

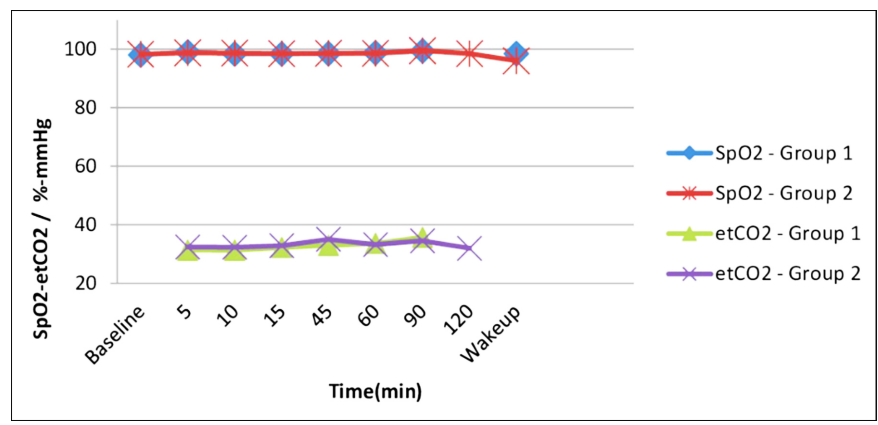

Figure 3: Change of SpO2 and etCO2 according to time by grooups.

\section{CONCLUSION}

In conclusion, the authors have found that low-flow sevoflurane anesthesia in laparoscopic chlocystectomy cases did not affect the thiol-disuphide homoestasis, IMA, haemodynamics, and oxygenation. Given adequate knowledge, suitable instruments for anesthesiology and the required monitors, the low-flow anesthesia can be applied as safely as the high-flow anesthesia technique. There is need for further research on the longer term postoperative effects and the effects during long lasting surgeries of the minimal and metabolic-flow anesthesia techniques.

\section{ETHICAL APPROVAL:}

Ethics Committee approval (2011-KAEK-25 2020/01-21; and Clinical trials No. NCT04926480).

\section{PATIENTS' CONSENT:}

All participants provided informed consent before taking part in the study.

\section{CONFLICT OF INTEREST:}

The authors declared no conflict of interest.

\section{AUTHORS' CONTRIBUTION:}

SE, SEO, UK, DK, YU: Conception, design, acquisition, analysis, and interpretation of data.

$\mathrm{SE}, \mathrm{SEO}, \mathrm{UK}, \mathrm{AD}, \mathrm{DK}, \mathrm{HE}$ : Drafting and revising it critically for important intellectual content.

SE, SEO, UK, AD, MG, YU, DK, HE, OE: Agreed to be accountable for all aspects of the work in ensuring that questions related to the accuracy or integrity of any part of the work are appropriately investigated and resolved. Gave final approval of the version to be published.

\section{REFERENCES}

1. Ozgunay SE, Ustundag $Y$, Karasu D, Uguzat II, Erel O, Korfali G, et al. The effect of different intraabdominal pressures on thiol/disulfide homeostasis in children who underwent ambulatory laparoscopic surgery: A prospective randomised study. J Laparoendosc Adv Surg Tech A 2018; 28(9):1142-7. doi:10.1089/lap.2017.0714.

2. Tanriverdi TB, Tercan M, Halitoglu AG, Kaya A, Patmano G. comparison of the effects of low-flow and normal-flow desflurane anaesthesia on Inflammatory parameters in patients undergoing laparoscopic cholecystectomy. Turk J Anesth Reanim 2021; 49(1):18-24. doi: 10.5152/TJAR. 2020.30.

3. Upadya M, Saneesh PJ. Low-flow anaesthesia-underused mode towards "sustainable anaesthesia. Indian J Anaesth 2018; 62(3):166-72. doi: 10.4103/ija.IJA_413_17.

4. Öterkuş M, Dönmez i, Nadir AH, Rencüzoğulları i, Karabağ $Y$, Binnetoğlu K. The effect of low flow anesthesia on hemodynamic and peripheral oxygenation parameters in obesity surgery. Saudi Med J 2021; 42(3):264-9. doi: 10.15537/smj.2021.42.3.20200575.

5. Kazancıoğlu L, Batçık S, Erdivanlı B, Şen A, Dursun E. Comparison of the effects of minimal and high flow anesthesia on cerebral perfusion during septorhinoplasty. Turk J Anesth Reanim 2021; 47(1): 12-6. doi: 10.5152/ TJAR.2018.36786.

6. Lee YM, Song BC, Yeum KJ. Impact of volatile anesthetics on oxidative stress and Inflammation. Biomed Res Int 2015; 242709. doi.org/10.1155/2015/ 242709.

7. Nesek-Adam V, Vnuk D, Rasić Z, Rumenjak V, Kos J, Krstonijević $Z$. Comparison of the effects of low intra-abdominal pressure and pentoxifylline on oxidative stress during $\mathrm{CO}_{2}$ pneumoperitoneum in rabbits. Eur Surg Res 2009; 43(4):330-7. doi: 10.1159/000237747.

8. Erel Ö, Erdoğan S. Thiol-disulfide homeostasis: An inte- 
grated approach with biochemical and clinical aspects. Turk J Med Sci 2020; 50(SI-2):1728-38. doi: 10.3906/ sag-2003-64.

9. Bar-Or D, Lau E, Winkler JV. A novel assay for cobalt albumin binding and its potential as a marker for myocardial ischemia-a preliminary report. J Emerg Med 2000; 19(4): 311-5. doi: 10.1016/s0736-4679(00) 00255-9.

10. Cam V, Olgac A, Kilic, Erel O, Neselioglu S, Kasapkara CS. Oxidative Stress in Intoxication Type Inborn Errors of Metabolism using Thiol-Disulfide Ratio. J Coll Physicians Surg Pak 2021; 31(6): 663-7. doi: 10.29271/jcpsp. 2021.06.663.

11. Erel O, Neselioglu S. A novel and automated assay for thiol/disulphide homeostasis. Clin Biochem 2014; 47(18):326-32. doi: 10.1016/j.clinbiochem. 2014.09. 026.

12. Sbarouni E, Georgiadou P, Voudris V. Ischemia modified albümin changes-review and clinical implications. Clin Chem Lab Med 2011; 49(2):177-84.doi: 10.1515/CCLM. 2011.037.

13. Shevtsova A, Gordiienko L, Tkachenko V, Ushakova G. Ischemia-Modified Albumin: Origins and Clinical Implications. Dis Markers 2021; 2021(18): 9945424. doi: $10.1155 / 2021 / 9945424$

14. Ozcan ATD, Doger C, Ozturk L, Yungul A, Kurtsahin M, Neselioglu $S$, et al. Comparison of the effects of sevoflurane and desflurane on thiol-disulfide homeo-stasis in patients undergoing laparoscopic cholecystectomy. Eurasian J Med 2019; 51(1): 70-4. doi: 10.5152/eurasianjmed.2019.18299.

15. Polat M, Özcan Ö, Sahan L, Ustündag-Budak Y, Alisik M, Yilmaz $\mathrm{N}$, et al. Changes in thiol-disulfide homeostasis of the body to surgical trauma in laparoscopic cholecystectomy patients. J Laparoendosc Adv Surg Tech A 2016; 26(12) :992-6. doi: 10.1089/lap.2016. 0381.

16. Sonmez MG, Kozanhan B, Deniz CD, Goger YE, Kilinc MT, Neselioglu S. et al. Is oxidative stress measured by thiol/disulphide homeostasis status associated with prostate adenocarcinoma? Cent Eur J Immunol 2018; 43(2):174-9. doi: 10.5114/ceji.2017.72285.

17. Yakan S, Atakisi O. Effects on the lipid peroxidation and the antioxidant defense systems of the use of Isoflurane or sevoflurane in calves undergoing surgery. Acta Sci Vet 2021; 49. doi: 10.22456/1679-9216.111714

18. Kundović SA, Rašić D, Popović L, Peraica, M, Črnjar K. Oxidative stress under general intravenous and inhalation anaesthesia. Arh Hig Rada Toksikol 2020; 71(3): 169-77. doi: 10.2478/aint-2020-71-3437.

19. Erbas M, Demiraran Y, Yildirim HA, Sezen G, Iskender A, Karagoz I, et al. Comparison of effects on the oxidant/ antioxidant system of sevoflurane, desflurane and propofol infusion during general anesthesia. Rev Bras Anestesiol 2021; 65(1):68-72. doi: 10.1016/j.bjan.2014. 05.002 .

20. Kaya-Ugur B, Erkutlu I, Saracaloglu A, Geyik AM, Demiryürek $S$, Demiryürek AT. Comparison of serum dynamic thiol/disulfide homeostasis and nitric oxide levels of total intravenous versus inhaled anesthesia in endoscopic transsphenoidal pituitary surgery. Int J Clin Pract Suppl 2021; 75(9): e14485. doi: 10.1111/ijcp. 14485.

21. Batçık Ş, Kazancıoğlu L, Arpa M, Bahceci İ, Erel, Neşelioglu S. The effect of minimal-flow and high-flow hypotensive anesthesia on oxidative stress. Mid Blac Sea J Health Sci 2021;7(2), 221-9. doi: 10.19127/ mbsjohs.936739.

22. Yüce HH, Küçük A, Altay N. Minimal flow anesthesia vs low flow anesthesia in terms of oxidative stress and cost effectivity in patients undergoing thyroid/ parathyroid surgery. J Harran UnIv Med Fac 2016; 13(1).

23. Dogan G, Kayir S, Demir E, Yavuz Y, Hanci V. The effect of minimal, low and medium flow anesthesia on intraoperative neuromuscular blocker consumption: Prospective cohort study. J Ankara Univ Fac Med 2019; 72(3): 356-62.

24. Kepekci AB, Omaygenc DÖ, Karaca IO, Telli S, Yücepur S, Özenc $E$. Even lower is possible: Impact of flow rate on safety issues in low flow anaesthesia. Med J Bakirkoy 2019; 15(1): 15-23. doi: 10.4274/BTDMJB.galenos.2017. 20171005064643.

25. Isik Y, Goksu S, Kocoglu H, Oner U. Low flow desflurane and sevoflurane anaesthesia in children. Eur J Anaesthesiol 2006; 23(1):60-4. doi: 10.1017/S02650215 0500178X. 